\title{
Principal's Leadership in Improving the Quality of Learning
}

\author{
Saca $^{1 *}$, Happy Fitria $^{2}$, Yessi Fitriani ${ }^{2}$ \\ ${ }^{1}$ SD Negeri 10 Muara Telang, Banyuasin Regency \\ ${ }^{2}$ Universitas PGRI Palembang, Indonesia \\ *Corresponding author. Email: saca2565@gmail.com
}

\begin{abstract}
This study aims to describe the principal's leadership in improving the quality of learning at SD Negeri 10 Muara Telang and to analyze the obstacles and solutions to the principal's leadership in improving the quality of learning at SD Negeri 10 Muara Telang. Data collection was carried out by interview, observation and documentation. The data were analyzed using the stages of data reduction, data presentation, and conclusion drawing. From the research results it can be concluded that the principal's leadership includes aspects, a) how to communicate which is in the very good category by providing clear, good, fluent, well-structured and efficient information, b) giving motivation that is in the very good category by motivating, directing, and providing solutions, c) the ability to lead is in the very good category with participatory and active, d) decision making is in the very good category with decisions based on deliberation to reach a consensus, and e) positive power is in the very good category with a sense of comfort and atmosphere kinship by the principal at SDN 10 Muara Telang, Banyuasin Regency. Aspects of education quality are based on Government Regulation Number 19 of 2005 concerning National Education Standards covering, competency standards for graduates, process standards, content standards, assessment standards, education and education staff standards, infrastructure and management standards, management standards and good financing standards.
\end{abstract}

Keywords: Leadership, Principal, Learning Quality

\section{INTRODUCTION}

Education is a community need that is expected to be able to create quality humans, to realize these expectations formally education is held in schools. The goals of education can be achieved if in its implementation it is managed properly starting from the process of planning, organizing, implementing, and evaluating [1].

As stated in the Republic of Indonesia [2] concerning the national education system article 10 paragraph 2 states that schools are a forum for implementing a continuous and tiered teaching and learning process, so it can be said that schools are organizations that have the authority to organize teaching and learning activities for realizing the goals of national education.

Improving the quality of education is the responsibility of all parties. Government involvement is also needed to continuously make improvements and refinement of education so that it is of higher quality. There are various kinds of factors that influence the success of educational institutions in improving the quality of education, one of which is the leadership aspect of the school principal. In the implementation of education, the principal has a central position and is responsible for the implementation of the teaching and learning process in schools. The principal is responsible for optimizing the management of human resources, facilities and infrastructure, finance, and information so that school goals can be achieved.

The job of school principals is quite heavy and requires extra skills, making school principals required to have skills that can make it easier for school principals to carry out their duties and responsibilities. Therefore, the government sets certain standards that the principal must meet as a leader of educational institutions. This is as stated in the Regulation of the Minister of National [3] which stipulates that there are two standards for school / madrasah principals, namely qualification standards and competency standards. In general, the qualification standards for principals include, having academic qualifications (S1), maximum age 56 years, having teaching experience of at least five years, rank as low as class III/c or equivalent. Meanwhile, the special qualifications for school principals are teacher status, certified educator, and certified principal. Meanwhile, in the competency standard, there are five competencies that the principal of a school / madrasah must have, namely, personality competence, managerial competence, entrepreneurial 
competence, supervisory competence, and social competence.

The realization of the goals of national education is inseparable from the managerial competence of the principal in managing educational institutions appropriately and professionally. The principal managerial competence itself is defined as the principal's ability to implement management functions starting from the planning, organizing, controlling, and optimizing utilization of school resources. The managerial competence of the principal will determine the sustainability of the activities of the educational institution. So that the principal must have good managerial competence and be supported by leadership behavior that is in accordance with what the school needs and be able to control conflict in schools in order to increase teacher productivity at work [4].

All management activities starting from the process of planning, organizing, implementing, leading, controlling school activities and optimizing the utilization of school resources are the responsibility of the principal as the education manager. Not only that, all school managerial activities, both operational and functional in an effort to achieve predetermined goals, must also be ensured by the principal that they can be carried out properly. Professional school principals are school principals who can act as effective managers by utilizing all resources owned by the school, starting from the use of facilities and infrastructure, buildings, facilities, and human resources [5].

As stated by Mantja [6], the effectiveness of the principal's managerial competence can be seen from the achievement of two indicators, namely: 1) the achievement of common goals (schools) as an organization that works together; 2) the fulfillment of all the needs of its members. (teachers and staff). So that the effectiveness of the performance of members in an educational institution is determined by the skills of the principal in carrying out management functions.

Therefore, the professionalism and high commitment of the principal is always required to carry out his duties as a leader who controls all wheels of education in order to achieve the goals of national education. In other words, the leadership quality of the principal will also determine the quality of education. Supriadi [1] states that: "There is a close relationship between the quality of school principals and various aspects of school life such as school discipline, school cultural climate and decreased student misbehavior." The effectiveness of teacher performance depends on the principal's ability to motivate teachers, create a conducive work climate, and increase teacher confidence in carrying out their responsibilities.

The availability of professional teachers who are able to carry out their duties and responsibilities properly is one of the factors that need to be considered in improving the quality of education. The teacher is the main key in any learning process in the classroom because the teacher's role is in a strategic position, especially in basic education. The learning process will still run even without buildings and other physical facilities, but the learning process in schools will not be able to run without teachers teaching. The teacher is in charge of designing, implementing, and evaluating learning. So, it is not surprising if the teacher is said to be a determinant of the success and success of the learning process in schools. Educational goals will be achieved if the learning process is carried out by professional and responsible teachers. The success of the teacher in the learning process will have an impact on improving the quality of education.

The results of this productive teacher performance can be seen from student learning outcomes and student achievements. The more productive the performance of a teacher, the learning outcomes and student achievement will increase because the teacher's excellent performance will have an impact on the high student achievement. "Therefore, in carrying out the learning process the teacher must hold several principles, namely having a high commitment to improving the quality of education, organizing a quality learning process, conducting assessments and evaluations to determine the extent of the success rate of the learning process that has been carried out, and providing good role models. for student. Therefore, the managers and consumers (students and parents of students) really care about the results of teacher performance. This has led to various efforts to improve the quality of teacher performance, one of which is by conducting performance appraisals.

Improving the quality of learning and teacher professionalism is absolutely necessary because teachers are the center of learning initiatives. In an effort to improve the quality of teacher learning, principal managerial skills as leaders in educational institutions are needed. It takes a strong principal who has a clear and directed vision and mission. By being able to carry out their managerial competencies effectively, the teacher will be motivated to contribute in an effort to realize the goals the school wants to achieve. There are several factors that can affect teacher performance, such as the ability and skills of the teacher, the availability of facilities and infrastructure, media, and learning resources that support the learning process. To improve teacher competence not only by involving teachers in various training events, seminars, or providing opportunities to continue higher education but more than that, the principal must also pay attention to other aspects such as increasing discipline, conducting regular supervision, providing motivation and guidance, providing salaries and rewards for outstanding teachers are also needed to fulfill the welfare of teachers as educators

Based on the results of temporary observations made by researchers, it is known that the principal at SD Negeri 10 Muara Telang has served as school principal for two terms and has been running for three years in 
this second period. The principal of SD Negeri 10 Muara Telang was able to compile a work program plan to increase productivity and direct the improvement of school personnel learning to run as expected. The work program drawn up by the principal per academic year 20 $20 / 20 \quad 21$ which covers the management and development of all areas ranging from curriculum, student affairs, infrastructure, public relations, teachers and education personnel, religious, administrative, and general fields. One of the activities in the work program is the implementation of learning supervision that is routinely carried out by the principal once a month.

Results of supervision documents show that $\mathrm{g}$ uru SD Negeri 10 Muara Taleang able to develop a learning plan well and skilled in managing the class. However, from the results of the supervision it was also known that there were some teachers who had problems in their learning. The identification of these problems is that some SD Negeri 10 Muara T e lang teachers still use conventional learning methods as well as the weak orientation of the student learning system. Although routine supervision is carried out by the principal, its implementation still needs to be improved.

From the problems mentioned above, it is appropriate to carry out research to determine the role of principal leadership in improving the quality of learning. Where the quality of learning is the spearhead in educating participants to understand the material presented so that expectations can have an impact on increased learning outcomes as well.

In conducting or investigating, certain tools are needed. For the object to be studied, the discussion is too broad, so it requires restrictions, in the discussion through which it is the object of research, so that this research can focus on the real problem. Leadership has been included in the category of applied science from the applied science of social sciences, because the principles, definitions and theories are expected to be useful for efforts to improve people's lives [7] Another case with the opinion put forward by Indrafachrudi [8] leadership is: It means the ability and readiness of a person to be able to influence encouraging, inviting, guiding, mobilizing and if necessary forcing others to accept that influence and then do something that can help to achieve something intent or purpose - the purpose specified.

The quality of learning is an indicator to see productivity and is closely related to management or management problems in schools. This can be related to the statement "quality failure in an organization is caused by management falsehoods" [9].

Schools as an organization in improving quality must see all aspects of the school components. So that all school components are responsible for their respective duties and functions. Total quality is total in three sense: it covers every process, every job, and every person. Quality national [10] education is directed at developing the potential of students to become human beings who believe and fear the Almighty God, have noble character, are healthy, knowledgeable, competent, creative, independent, and become democratic and responsible citizens.

The role of the principal is "someone who is specially appointed to occupy a certain position who has the main task and responsibility for the smooth implementation of education and teaching in schools.

According to Mano and Triyo [10] a school principal has a main function:

a. Responsible for the safety, welfare and development of students in the school environment

b. Responsible for the success and welfare of the teaching profession

c. Obliged to provide fully valuable services for students and teachers that may be carried out through other official supervision

d. Responsible for getting maximum assistance from all supporting institutions

e. Responsible for promoting the best student peseta in various ways.

The role of a leader, will determine where and what organization he leads. So that the presence of a leader will make the organization into a single unit that has the power to develop and grow bigger. Likewise, the head of madrasah, as the leader of a formal education institution, has a very important role in empowering education personnel.

\section{METHODS}

The method here describes what methods are used in research. With the method is expected to be a guide for researchers in carrying out research in accordance with the goals and objectives to be achieved.

The method in this study uses a qualitative descriptive method with a case study approach. According Moleong to [11]. Meanwhile, according to Sudjana [12], qualitative research is often used to produce grounded theory, which is a theory that arises from data not from hypotheses like in quantitative research.

In general, case studies are a more suitable strategy when the research question is about how or why, if the researcher has little opportunity to control the events to be investigated, and when the focus of the research lies on contemporary (present) phenomena in the context of real life [13].

\section{RESULTS AND DISCUSSION}

Principal leadership means empowering and utilizing existing resources that can be held efficiently and effectively to achieve the vision and mission of the 
school. The principal is responsible for the running of the school institution and its activities.

The school principal is at the forefront of carrying out his leadership and his success can be measured. The final product of principal leadership is school performance that changes both for teachers and students. The change of teachers and students from not knowing to knowing, from inexperienced to experienced, from being unable to become able, from not achieving to being high achievers. Meanwhile, the principal's leadership target is to improve the quality of education. So, the leadership of the principal has a strong role in shaping the quality of the people he leads to become the nation's next reliable generation.

The leadership implementation of the principal at SDN 10 Muara Telang, Banyuasin Regency in general is as follows:

\section{a. How to Communicate}

Based on the results of the study, it was found that communication methods were in the very good category by providing clear, good, fluent, well-structured and efficient information. The ability to communicate for a leader which in this case the principal has a very important role, where communication determines the direction of policies and decisions taken by him. For this reason, communication is good if both the principal as the sender of the information (sender) and the teacher or staff as the receiver of the information (receiver) are well established, so that all directions, instructions can be carried out properly. This will have an impact on the results or performance shown by his subordinates.

\section{b. Motivation}

Motivation in the very good category by motivating, directing, and providing solutions. $\mathrm{M}$ emberikan encouragement (motivation) is one of the factors that will determine the success of his school principal in the lead. An educational unit which is a social system, in which it consists of individuals who have different characteristics and are related (to serve) one another. In such conditions, the motivation of the principal is needed to support the growth and development of the organization (school).

\section{c. Leadership ability}

The ability to lead is in the very good category with participatory and active. All the efforts and leadership styles applied by the principal are none other than the creation of targets or goals that have been set by the school in the form of the school curriculum, because the principal as the top leader is a determining factor in the success of the school organization. A quality leader will greatly affect the success of achieving school quality, because the principal as a reliable leader will be able to manage the overall process of all school activities so that it affects constructively those who are under their responsibility so that they are always on the right track in fulfilling the objectives already planned by the school.

\section{d. Decision-making}

Decision making is in the very good category with decisions based on deliberation to reach a consensus. The decision-making process carried out by the principal is carried out by the existence of stages of observation, data collection, planning and identifying problems related to school education, then conducting deliberations between teachers, to make a policy or decision, the principal undertakes an approach- an interpersonal approach to teachers for organizing activities, supervision as controlling activity carried out by the principal as outlined in teacher work assessments, to increase the potential of principal teachers to participate in training and competition activities .

Principals must have basic skills as managers, namely: 1) technical skills; 2) human relation skills, and 3) conceptual skills technical skills with regard to the special knowledge required to carry out the main functions as a school supervisor. These technical skills include classroom observation, setting teaching goals, developing teaching systems, demonstrating teaching skills to carry out research. Human relations skills (human relations skills) are related to the principal's ability to cooperate with motivating teachers to work seriously. This skill responds to individual differences, listening to suggestions from others, solving conflicts and giving good examples. Meanwhile, conceptual skills are the principal's ability to make decisions and see important relationships in achieving goals. This activity also includes priorities, analyzing the environment, monitoring and controlling class activities.

\section{e. Positive Power}

Positive power is in the very good category with a sense of comfort and a kinship atmosphere by the principal. Positive power here is also often interpreted as democratic power, namely having the ability to listen to input and direction from subordinates before deciding on policies and decisions that will be carried out by subordinates.

To carry out educational programs properly, a measurable and directed guideline or reference is needed. Therefore, the government has issued Government Regulation Number 19 of 2005 concerning National Education Standards which was later refined by Government Regulation Number 32 of 2013.

\section{CONCLUSION}

From the research results it can be concluded that the principal's leadership includes aspects: a) how to communicate which is in the very good category by providing clear, good, fluent, well-structured and efficient information; b) giving motivation that is in the 
very good category by motivating, directing, and providing solutions; c) the ability to lead is in the very good category with participatory and active; d) decision making is in the very good category with decisions based on deliberation to reach a consensus, and e) positive power is in the very good category with a sense of comfort and atmosphere kinship by the principal at SDN 10 Muara Telang, Banyuasin Regency. Aspects of education quality are based on Government Regulation Number 19 of 2005 concerning National Education Standards covering, competency standards for graduates, process standards, content standards, assessment standards, education and education staff standards, infrastructure and management standards, management standards and good financing standards.

\section{ACKNOWLEDGMENTS}

Our deepest gratitude goes to Teachers in SD Negeri 10 Muara Telang, Banyuasin Regency, Chancellor of Palembang PGRI University, Director of the Postgraduate Program of PGRI Palembang University and the Education Management Study Program of PGRI Palembang University, who have supported us in doing this extraordinary thing. This project is funded independently. We also want to thank our Education Management friends who helped us a lot in a short time frame to complete this project.

\section{REFERENCES}

[1] Mulyasa, E. (2013). Menjadi kepala sekolah Profesional [Become a professional school principal]. Bandung: PT. Remaja Rosdakarya.

[2] Undang-Undang Republik Indonesia Nomor 20 tahun 2003 tentang Sistem Pendidikan Nasional. Law of the Republic of Indonesia Number 20 of 2003 concerning the National Education System.

[3] Permendiknas No. 16 Tahun 2007 tentang standar kualifikasi akademik dan kompetensi guru. Permendiknas No. 16 of 2007 concerning academic qualification standards and teacher competencies.

[4] Werang, A. (2012). Manajemen Kepemimpinan Kepala Sekolah [Principal Leadership Management]. Jakarta: Rineka Cipta.

[5] Ernie, N. (2015). Landasan Manajemen Pendidikan [Educational Management Foundation]. Bandung: PT Remaja Rosdakarya.

[6] Kempa, R. (2011). Kepemimpinan Kepala Sekolah [Principal Leadership]. Jakarta: Rineka Cipta.

[7] Kartono, K. (2013). Pemimpin dan Kepemimpinan: Apakah Kepemimpinan Abnormal Itu? [Leadership and Leadership: What Is Abnormal Leadership?] Jakarta: Raja Grafindo Persada.
[8] Indrafachrudi. (2013). Bagaimana Memimpin Sekolah yang Efesien [How to Lead an Efficient School]. Bandung: Alfabeta.

[9] Ahmad, S. (2013). Ketahanmalangan Kepemimpinan Kepala Sekolah: Salah Satu Faktor Penentu Keberhasilan Kepala Sekolah [Headmaster Leadership Resilience: One of the Determining Factors of the Principal's Success]. Yogyakarta: Deepublish.

[10] Mano, M., \& Triyo, A. (2018). Peranan Kepala Sekolah dalam Meningkatkan Kinerja Guru [The Role of the Principal in Improving Teacher Performance]. Tesis: Tidak Dipublikasikan.

[11] Moleong, L. (2011). Penelitian: Kualitatif [Research: Qualitative]. Bandung: Alfabeta.

[12] Sudjana. (2010). Metode Statistika [Statistical Methods]. Bandung: Alfabeta.

[13] Yin, R. K. (2011). Studi Kasus [Case study] Jakarta: Raja Grafindo Persada. 